Orissa Journal of Commerce

Vol. 42, Issue 2, April-June 2021

ISSN: 0974-8482

(C) OJC India. All Right Reserved

URL: www.ojcoca.org

DOI: https://doi.org/10.54063/ojc.2021.v42i02.06

\title{
Exploring the Intrapreneurship Dimensions for Industrial Auto Clusters: A Study in Delhi-NCR Region
}

\author{
Lalit Chhabra ${ }^{1}$ and Vandana Mehrotra ${ }^{2}$ \\ ${ }^{1}$ Ph.D Scholar, GD Goenka University, Gurgaon, Haryana.E-mail: lalitkc007@gmail.com \\ 2Associate Professor, G D Goenka University, Gurgaon, Haryana. E-mail: vandana.mebrotra@gdgoenka.ac.in
}

\author{
To cite this paper \\ Chhabra, L., \& Mehrotra, V. \\ (2021). Exploring the \\ Intrapreneurship Dimensions for \\ Industrial Auto Clusters: A Study \\ in Delhi-NCR Region. Orissa \\ Journal of Commerce. 42(2), 68-81
}

Keywords

Intrapreneurship, Dimensions of intrapreneurship, Auto clusters, EFA and CFA.

JEL Classification L10, L22, L90, L91

\begin{abstract}
Recently, 'Intrapreneurship' is recognized as an indispensable strategy to build firms innovative capabilities, gain value linked competence, and financial returns quickly. So, it is imperative to unveil key dimensions of intrapreneurship for revitalizing firm's growth in the automobile sector. The main objective is to determine the key intrapreneurship dimensions in the Auto Clusters in Delhi/ NCR. For this, the quantitative data were gathered from 300 executive/ managers using structured questionnaires and data were analysed using the "Exploratory Factor Analysis (EFA) and Confirmatory Factor Analysis (CFA)". This led to a 6-dimension structure of intrapreneurship, consistent with the extant studies. The study concluded with the important implications of the intrapreneurship dimensions in the auto clusters that will pave way for other studies. This study is confined to auto clusters in Delhi/NCR, however, there is further scope of extending this research to other industries in different geographical areas.
\end{abstract}

\section{Introduction}

In the realm of industrial transformation, a new paradigm called 'Intrapreneurship' has attracted a lot of attention from academia and industry as reflected in the increased publications (Alam, M., et al, 2020; Neessen. et al., 2019). Intrapreneurship refers to the "phenomenon of entrepreneurship in already existing organizations (Antoncic and Hisrich, 2001), and embodies activities of new internal and external business venturing, transformation through innovation and strategic renewal (Parker, 2011)." Regarded as an offshoot of entrepreneurship, it is recognized as an important means to rejuvenate firms through strategic renewal, innovation and venturing process (Stopford and Baden-Fuller, 1990), for firm's development (Kakati, 2003), to strengthen competencies through enhancing knowledge and skills for a competitive advantage (Hornsby et al., 2002). Further, aligning with the resource-based view, its role is considered vital for resource utilization leading to firm advantage (Floyd and Wooldridge, 1999), creating an innovation culture for entrepreneurial pursuits for excellence (Lukes and Stephan, 2017). It spurs innovations through the firm's proactiveness in the market leading to growth and profitability 
(Miles and Covin, 2002). So, Intrapreneurship is the foundation stone for innovation and performance to align with competitive challenges.

The term was first pioneered by Pinchot (1985). It is a combination of two concepts: 'intra corporate and 'entrepreneur'. Intrapreneurship is 'entrepreneurship within organizations. It imbibes the spirit of entrepreneurial orientation across all the levels and departments in an organization and so, is quite distinctive of the organizational culture prevalent in a particular organization. The extant theory cites that 'Intrapreneurship' can be regarded to be similar to entrepreneurship, but it is different in the context despite similarity in the two. The former, encompasses entrepreneurial orientation in perceiving new opportunities proactively rather than reacting to state of things complacently (Stevenson and Jarillo, 1990). So, Intrapreneurship is conceptualized as reformative processes; a way of doing things not only differently but moving ahead beyond the traditional ways of doing things to stay ahead of competitors. It is also reckoned as ways in which employees foresee opportunities beyond the resources they own or control (Blanka, 2019; Neessen. et al., 2019). Thus, it is a behavioural intention that is divergent and distinctive in traditional ways of doing things. (Antoncic and Hisrich, 2003, 2004). In a recent systematic review of the literature, Neessen et al. (2019) affirmed that key dimensions of intrapreneurship include- "innovativeness, proactiveness, risk-taking, opportunity recognition, and external networking".

Due to its strategic importance in firm growth and renewal, there has been plethora of studies focusing on conceptual formulations and empirical studies on intrapreneurship (Antoncic and Hisrich, 2001; Champathes and Swierczek, 2002; Wiklund and Shepherd, 2003). However, there are less studies concentrating on the key dimensions of intrapreneurship (Augusto Felício et al., 2012; Chawla and Lenka, 2015; Kassa and Raju, 2015; Vargas et al., 2017). Augusto, et al. (2012) in the study enumerated 6 main dimensions of intrapreneurship, as- "innovation, risk/uncertainty, risk/challenges, competitive energy, proactiveness and autonomy, productivity, improvement, financial performance, and growth". But most of the studies relate to the antecedents and orientation and pertain to the developed economies with scant studies in the context of emerging economies, like India. This study plugs in this major research lacuna to unravel the key dimensions spurring intrapreneurship in the context of Indian auto clusters. In this backdrop, this study attempts to explore and validate the Intrapreneurship dimensions that comply with the Indian auto clusters which are presently juggling with resource allocations amidst a robust networking, competitive industry, and changing government policy. The study contributes in threefold ways, one by lending a conceptual clarity since it is fragmented and employs several perspectives. Second, it closes a major research lacuna by exploring the Intrapreneurship dimensions in the Indian auto clusters which is one of the dominant auto sectors contributing to the economic development of the nation. Moreover, such a study will guide other similar studies in various clusters, primarily to derive networking benefits for enhancing their performance.

\section{Review of Literature}

Intrapreneurship is conceptually derived from the theoretical underpinnings surrounding entrepreneurship. It relates to "Schumpeterian innovation dimensions as: corporate venturing, strategic renewal, and spin-offs for ideas generation" (Zahra, 1991). 
The experts have extensively dwelled on its importance as instrumental for firm rejuvenation (Pinchot and Pellmann, 1999), and the dynamic force behind the firm's innovative capability (Wennekers and Thurik, 1999; Carree and Thurik, 2003). As per Kuratko (2007), it is linked to tapping opportunities leading to innovations and capability building. In a similar vein, Fernald, et al. (2005) linked it with risk bearing capabilities of firms, thereby, leading to innovations.

Previous studies have categorized Intrapreneurship into these dimensions, as New business venturing (Vesper,1984; Rule and Irwin, 1988; Zahra, 1991; Stopford and Baden-Fuller, 1994), Product/service innovativeness (Covin and Slevin, 1991; Zahra, 1991; Knight, 1997), Process/ technology innovativeness (Covin and Slevin, 1991; Damanpour, 1996; Tushman and Anderson, 1997; Antoncic, 2003), Self-renewal (Guth and Ginsberg, 1990; Zahra, 1991), Risk taking (Covin and Slevin, 1991), and Proactiveness (Covin and Slevin, 1991). They have defined these dimensions as follows:

\subsection{Dimensions of Intrapreneurship}

New business venturing is "the creation of new businesses related to existing products or markets and the creation of new units without regard to the level of autonomy or size." Innovativeness means "innovations in product/service offerings, production processes, procedures and techniques, as well as in technologies. Self-renewal "reflects in the transformation of organizations through a renewal of the key ideas on which they are built" Risk taking relates to "the firm adeptness in quickly quick pursuit of opportunities, fast commitment of resources and bold actions Proactiveness is "the extent to which organizations attempt to lead rather than follow competitors in key business ventures, entering new markets as new product development or introduction of new services operating technologies or administrative techniques".

\subsection{Intrapreneurship and Related Constructs}

Studies have affirmed that it will foster functional competencies of managers and employees, including operation, finance, marketing, and human resource functions that would lead to integration and assist in new strategic thinking and reformations. Jiang, 2009; Zaech and Baldegger, 2017). Besides, Intrapreneurship within firms will create entrepreneurial leaders through development of their personal competency (Bagheri, Pihie, and Krauss, 2013), managerial competency, proactive competency, and technological competency (Baylor and Ritchie, 2002). These competencies will encourage and contribute to adoption of the new policies, as in the case of Indian auto clusters.

\subsection{Outcomes of Intrapreneursbip}

Several important outcomes have also been cited by researchers, like firm performance as stated by Antoncic and Hisrich, (2003), growth and profitability as per Covin and Slevin, (1991). Remarkedly, studies have linked Intrapreneurship to firm growth, irrespective of its size, like in case of small-firm growth by Covin, (1991), large-firm growth (Covin and Slevin, 1989), and performance in hostile environments. So, it is important to understand Intrapreneurship in small and medium auto cluster firms in the current transition phase as taken up in this study. 
To sum up, from the above discussion, it can be inferred that Intrapreneurship will lead to development of products and services using high technology that leads to superior business performance.

\section{Objectives of the Study}

The main objectives of the study are:

- To determine the key dimensions of intrapreneurship in context of auto clusters in Delhi/ NCR.

- To validate the key dimensions of intrapreneurship in the context of auto clusters in Delhi/ NCR.

\section{Research Methodology}

To achieve the objectives, the study utilized a quantita tive cross- sectional study design approach based on the analysis of data generated through the questionnaires which was distributed online to executives and managers from the auto clusters in Delhi/NCR. India's automotive industry is spread across three clusters - Chennai in the South, Maharashtra in the West and the National Capital Region in the North. Since these auto clusters are heavily concentrated in the Delhi-NCR regions, so it has been taken up as the focal case point/context in this study. These auto clusters are quite competitive and resourceful deriving the advantages of networking and most importantly progressive and industry focused but presently facing a lot of challenges on account of technological transitions. A sample of 300 executives as respondents participated in the survey and the sampling method used was "cluster random sampling".

The minimum sample size needed for conducting EFA and CFA should be $\mathrm{N}=150$, with the EFA and CFA methods of analysis. (Mundfrom, Shaw, and Ke (2005).The "Intrapreneurship scale" was used which was derived from (Antoncic and Hisrich, 2004), which is actually combination of i) the ENTERSCALE of Khandwalla (1977), Covin and Slevin (1991), and ii) the corporate entrepreneurship scale of Zahra (1991). The responses were assessed through likert 5-point scale (1: Strongly Disagree - 5 Strongly Agree). Techniques of Exploratory Factor Analysis, EFA and Confirmatory Factor Analysis, CFA were run to unravel and confirm the "Intrapreneurship dimensions" in the auto clusters. EFA was run with the purpose of data reduction and component summarization and CFA was done to test and confirm construct validity for Intrapreneurship dimensions.

\section{Data Analysis and Findings}

\subsection{Demographic Profile}

The respondent profile of the 300 executives was aptly represented by 195 males (65\%) and with 105 females $(35 \%)$. In terms of educational level, 198 respondents $(66 \%)$ were holders of a bachelor's degree, while 102 respondents were Postgraduate (34\%). Majority of the respondents were 31-40 years $(45 \%)$ followed by $41-50$ years $(34 \%)$ and there were 65 respondents in the age group of above 51 years $(22 \%)$. 
Lalit Chhabra and Vandana Mehrotra

Table 1: Demographic Analysis

\begin{tabular}{lrr}
\hline Gender & Frequency & Percent \\
\hline Male & 195 & $65 \%$ \\
Female & 105 & $35 \%$ \\
Total & 300 & $100 \%$ \\
\hline Age & Frequency & Percent \\
\hline $31-40$ & 134 & $45 \%$ \\
$41-50$ & 101 & $34 \%$ \\
Above 51 & 65 & $22 \%$ \\
Total & 300 & $100 \%$ \\
\hline Education & Frequency & Percent \\
\hline Graduate & 198 & $66 \%$ \\
Post Graduate & 102 & $34 \%$ \\
Total & 300 & $100 \%$ \\
\hline
\end{tabular}

Source: Authors' Calculation

\subsection{Exploratory Factor Analysis}

In the first place, the EFA was run for data reduction and component summarization, and then Confirmatory factor Analysis, (CFA) was performed to test and confirm the "construct validity" for ascertaining the Intrapreneurship dimensions. Prior to administering EFA, the data was checked for EFA through Kaiser-Meyer-Olkin, KMO sampling adequacy measure, and Bartlett's test (Table 2). The KMO value was .850 , above the recommended value of .6 , and Bartlett's test of sphericity was significant $(\chi 2(351)=8455.509, \mathrm{p}<.05)$ in line with (Guttman, 1954; Tabachnick and Fidell, 2013). Further, Eigen value criteria $(>1)$ was applied for factor extraction.

Table 2: KMO and Bartlett's Test

\begin{tabular}{lll}
\hline Kaiser-Meyer-Olkin Measure of Sampling Adequacy. & & 0.850 \\
\hline Bartlett's Test of Sphericity & Approx. Chi-Square & 8455.509 \\
& df & 351 \\
& Sig. & 0.000 \\
\hline
\end{tabular}

Source: Authors' Calculation

The overall results of Promax rotation showed six factors with loadings greater than .50 (Guttman, 1954; Tabachnick and Fidell, 2013) with a total variance of $79.164 \%$ variance, which is a good measure. 


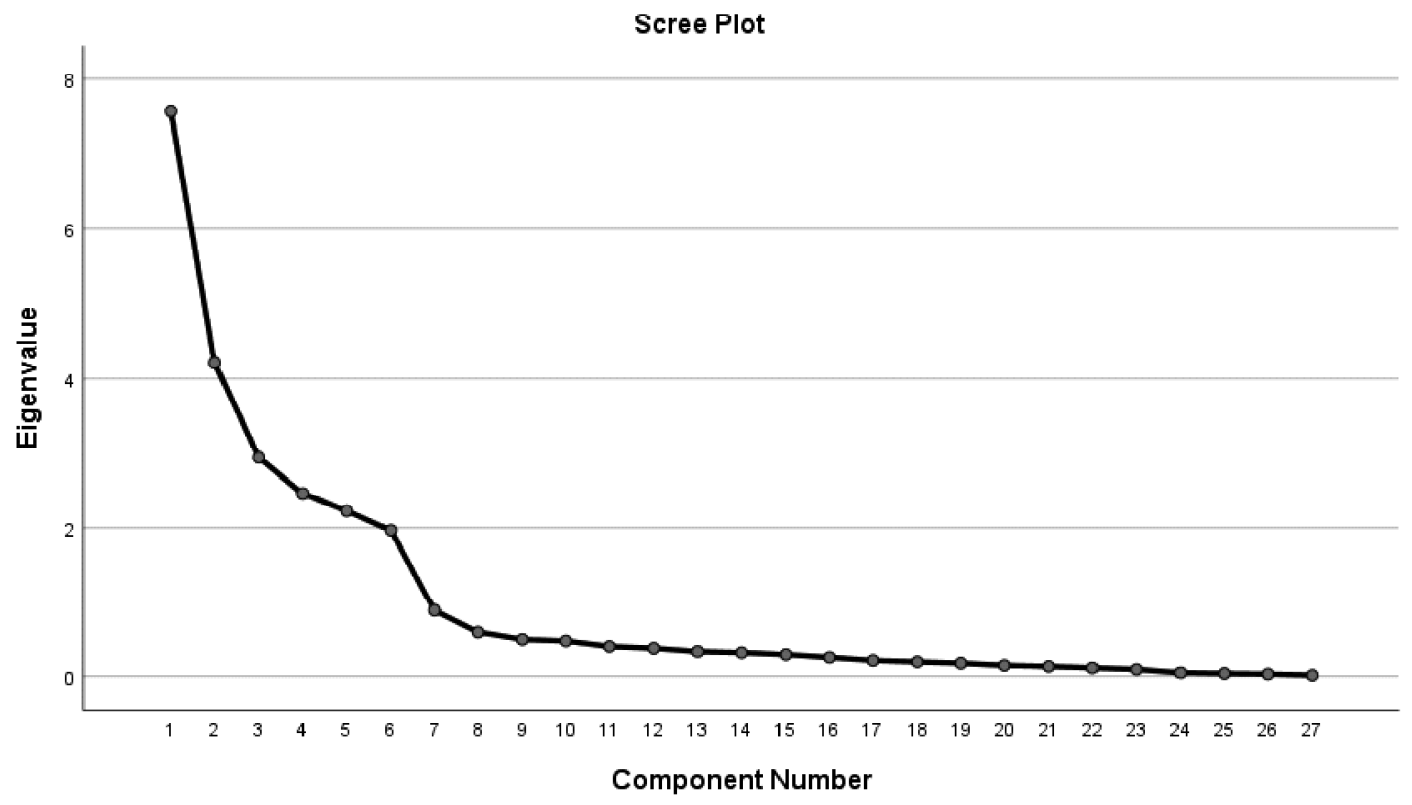

Figure 1: Scree Plot

Source: Authors' Calculation

Table 3: Factor Loadings, Variance and Reliability

\begin{tabular}{|c|c|c|c|c|c|}
\hline Constructs & Item Code & Statement (s) & Loading & Variance $(\%)$ & Reliability \\
\hline \multirow[t]{4}{*}{ Risk-taking } & ICRT1 & $\begin{array}{l}\text { Our firm has a strong proclivity for high- } \\
\text { return high-risk projects. }\end{array}$ & 0.921 & 9.097 & 0.924 \\
\hline & ICRT2 & $\begin{array}{l}\text { Our firm takes bold and wide-ranging acts } \\
\text { to achieve our objectives }\end{array}$ & 0.904 & & \\
\hline & ICRT3 & $\begin{array}{l}\text { Our firm adopts a bold, aggressive posture in } \\
\text { order to maximize the probability of exploiting } \\
\text { potential opportunities. }\end{array}$ & 0.902 & & \\
\hline & ICRT4 & Our firm encourages risk-taking behaviours. & 0.868 & & \\
\hline \multirow[t]{4}{*}{ Proactiveness } & ICPR1 & $\begin{array}{l}\text { Our firm typically initiates actions to which } \\
\text { competitors have to respond to. }\end{array}$ & 0.77 & 8.252 & 0.864 \\
\hline & ICPR2 & $\begin{array}{l}\text { Our firm is often the first to introduce } \\
\text { new products. }\end{array}$ & 0.87 & & \\
\hline & ICPR3 & $\begin{array}{l}\text { Our firm typically adopts a very competitive } \\
\text { strategy }\end{array}$ & 0.881 & & \\
\hline & ICPR4 & Our firm is proactive. & 0.867 & & \\
\hline
\end{tabular}

contd. table 3 
Lalit Chhabra and Vandana Mehrotra

\begin{tabular}{|c|c|c|c|c|c|}
\hline Constructs & Item Code & Statement $(s)$ & Loading & Variance(\%) & Reliability \\
\hline \multirow[t]{4}{*}{ Innovativeness } & ICIN1 & $\begin{array}{l}\text { Our firm has a strong emphasis on R\&D, } \\
\text { technological leadership and innovation }\end{array}$ & 0.819 & 7.292 & 0.764 \\
\hline & ICIN2 & $\begin{array}{l}\text { Our firm has had many new lines of products } \\
\text { in the past five years (or since its establishment). }\end{array}$ & 0.65 & & \\
\hline & ICIN3 & $\begin{array}{l}\text { Our changes in product lines have usually been } \\
\text { quite dramatic. }\end{array}$ & 0.874 & & \\
\hline & ICIN4 & $\begin{array}{l}\text { Our firm engages innovative behaviours } \\
\text { and activities }\end{array}$ & 0.53 & & \\
\hline \multirow[t]{5}{*}{$\begin{array}{l}\text { New } \\
\text { Business } \\
\text { Venturing }\end{array}$} & ICBV1 & $\begin{array}{l}\text { Stimulating new demand for existing products in } \\
\text { current markets through aggressive advertising }\end{array}$ & 0915 & 15606 & 0.48 \\
\hline & ICBV2 & Broadening business lines in current industries & 0.916 & 15.000 & 0.940 \\
\hline & ICBV3 & $\begin{array}{l}\text { Pursuing new businesses in new industries that } \\
\text { are related to current business }\end{array}$ & 0.918 & & \\
\hline & ICBV4 & $\begin{array}{l}\text { Finding new niches for products in current } \\
\text { markets }\end{array}$ & 0.943 & & \\
\hline & ICBV5 & $\begin{array}{l}\text { Entering new businesses by offering new lines } \\
\text { and products }\end{array}$ & 0.853 & & \\
\hline \multirow[t]{6}{*}{ Self Renewal } & ICSR1 & $\begin{array}{l}\text { Reorganizing units and divisions to increase } \\
\text { innovation }\end{array}$ & 0.834 & 28.052 & 0.95 \\
\hline & ICSR2 & $\begin{array}{l}\text { Increasing the autonomy (independence) of } \\
\text { different units to enhance their innovation }\end{array}$ & 0.919 & & \\
\hline & ICSR3 & $\begin{array}{l}\text { Adopting flexible organizational structures to } \\
\text { increase innovation }\end{array}$ & 0.833 & & \\
\hline & ICSR4 & Training employees in creativity techniques & 0.886 & & \\
\hline & ICSR5 & $\begin{array}{l}\text { Establishing procedures to solicit employee } \\
\text { ideas for innovations }\end{array}$ & 0.928 & & \\
\hline & ICSR6 & $\begin{array}{l}\text { Establishing procedures to examine new } \\
\text { innovation ideas }\end{array}$ & 0.925 & & \\
\hline \multirow{4}{*}{$\begin{array}{l}\text { Competitive } \\
\text { Aggressi- } \\
\text { veness }\end{array}$} & ICCA1 & I prefer aggressive price competition. & 0.976 & 10.865 & 0.971 \\
\hline & $\begin{array}{l}\text { ICCA2 } \\
\text { ICCA3 }\end{array}$ & $\begin{array}{l}\text { I try hard to take customers from competitors } \\
\text { I watch competitors' business strategies to react }\end{array}$ & 0.978 & & \\
\hline & & against them promptly & 0.96 & & \\
\hline & ICCA4 & $\begin{array}{l}\text { I prefer aggressive marketing of new menus and } \\
\text { services through the Internet }\end{array}$ & 0.973 & & \\
\hline
\end{tabular}

Source: Authors' Calculation 
So, the 6 main Intrapreneurship dimensions, as extracted from the Exploratory Factor Analysis, are: Self Renewal (Cronbach Alpha 0.95, Variance Explained 28.05\%), New Business Venturing (Cronbach Alpha 0.948, Variance Explained 15.60\%), Competitive Aggressiveness (Cronbach Alpha 0.971, Variance Explained 10.86\%), Risk-taking (Cronbach Alpha 0.924, Variance Explained 9.097\%), Proactiveness (Cronbach Alpha 0.864, Variance Explained 8.252\%), and Innovativeness (Cronbach Alpha 0.764, Variance Explained $7.292 \%)$.

This is followed by the CFA to test and confirm the validity of the key constructs/dimensions of Intrapreneurship, as per the study of objective 2 .

\subsection{Confirmatory Factor Analysis}

CFA is advocated and administered to affirm "construct validity" for Intrapreneurship dimensions, which will set the ground for examining the relationship between construct dimensions and their items (figure 2). The values establish the model fitness for the data (table 4).

As per the criteria, the ratio of goodness of fit to degrees of freedom should not exceed 3, and RMSEA $<0.08$, along with GFI, IFI, NFI, CFI values being $>0$.9. The smaller RMR indicates a better model fit (Hooper, et al., 2008). The value of RMSEA is $<0.08$ and CMIN/DF is $<3$ which indicates a good model fit (Fornell and Larcker, 1981).

Table 4: Model Fit Measures

\begin{tabular}{llccc}
\hline Model Fit Indices & Citation & ThresholdLimit & Estimated Value & Interpretation \\
\hline Normed Chi-Square & $\begin{array}{l}\text { Maclver, J. P., and Carmines, } \\
\text { E. G. (1981) }\end{array}$ & $<3$ & $\begin{array}{c}\text { 715.521 (282); } \\
\text { CMIN/DF - 2.537 }\end{array}$ & Excellent \\
\hline CFI & $\begin{array}{l}\text { MacCallum and Hong (1997), } \\
\text { Hu and Bentler (1999) Gefen, } \\
\text { D., Straub, D., and Boudreau, } \\
\text { M. C. (2000) }\end{array}$ & $>0.80$ & 0.95 & Acceptable \\
\hline RMSEA & $\begin{array}{l}\text { Browne and Cudeck (1989) } \\
\text { SRMR }\end{array}$ & $<0.08$ & & \\
\hline
\end{tabular}

Source for Criterion of Model Fit Measures align with Hair, et al (2009), Fornell and Larcker (1981).

\subsubsection{Validity Assessment}

The results show that Convergent validity assessment: (CR > 0.7; AVE < CR; $0.5<$ AVE) Validity of Discriminant: (AVE > MSV, ASV < AVE) hold good in the study (Fornell and Larcker, 1981; Hair et al, 2009) as per table 5. So, the measurement model has sufficient convergent validity and discriminant validity). 


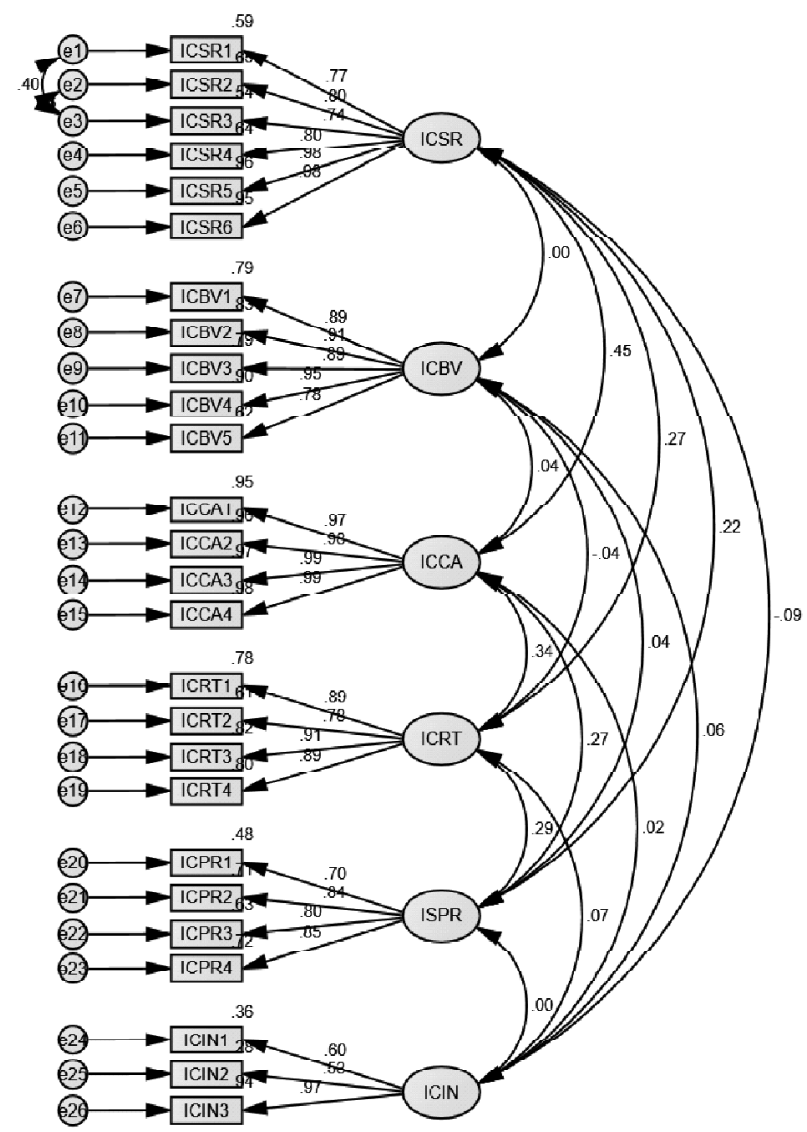

Figure 2: Confirmatory Model

Sources: Authors' Calculation

Table 5: Model Validity Measures

\begin{tabular}{lrrrr}
\hline & $C R$ & $A V E$ & $M S V$ & $M a x R(H)$ \\
\hline ICSR & 0.939 & 0.721 & 0.201 & 0.98 \\
ICBV & 0.948 & 0.787 & 0.003 & 0.959 \\
ICCA & 0.99 & 0.963 & 0.201 & 0.992 \\
ICRT & 0.925 & 0.755 & 0.118 & 0.933 \\
ISPR & 0.874 & 0.635 & 0.087 & 0.883 \\
ICIN & 0.757 & 0.527 & 0.008 & 0.943 \\
\hline
\end{tabular}

Source: Authors'Calculation 
Exploring the Intrapreneurship Dimensions for Industrial Auto Clusters

Table 6: Unstandardized and Standardised Weights

\begin{tabular}{|c|c|c|c|c|c|c|c|}
\hline & & & & $\begin{array}{l}\text { ardized } \\
\text { Weight. }\end{array}$ & & $P$ & $\begin{array}{l}\text { Standardized } \\
\text { Regression }\end{array}$ \\
\hline ICSR1 & $<-$ & ICSR & 1 & & & & 0.77 \\
\hline ICSR2 & $<-$ & ICSR & 1.05 & 0.07 & 15.32 & $* * *$ & 0.8 \\
\hline ICSR3 & $<-$ & ICSR & 0.97 & 0.05 & 17.74 & $* * *$ & 0.74 \\
\hline ICSR4 & $<-$ & ICSR & 0.98 & 0.06 & 15.24 & $* * *$ & 0.8 \\
\hline ICSR5 & $<-$ & ICSR & 1.26 & 0.06 & 19.81 & $* * *$ & 0.98 \\
\hline ICSR6 & $<-$ & ICSR & 1.26 & 0.06 & 19.76 & $* * *$ & 0.98 \\
\hline ICBV1 & $<-$ & ICBV & 1 & & & & 0.89 \\
\hline ICBV2 & $<-$ & ICBV & 1 & 0.04 & 24.67 & $* * *$ & 0.91 \\
\hline ICBV3 & $<-$ & ICBV & 0.91 & 0.04 & 23.14 & $* * *$ & 0.89 \\
\hline ICBV4 & $<-$ & ICBV & 1.06 & 0.04 & 27.31 & $* * *$ & 0.95 \\
\hline ICBV5 & $<-$ & ICBV & 0.75 & 0.04 & 17.93 & $* * *$ & 0.78 \\
\hline ICCA1 & $<-$ & ICCA & 1 & & & & 0.97 \\
\hline ICCA2 & $<-$ & ICCA & 1 & 0.02 & 53.7 & $* * *$ & 0.98 \\
\hline ICCA3 & $<-$ & ICCA & 0.98 & 0.02 & 58.18 & $* * *$ & 0.99 \\
\hline ICCA4 & $<-$ & ICCA & 1.01 & 0.02 & 60.52 & $* * *$ & 0.99 \\
\hline ICRT1 & $<-$ & ICRT & 1 & & & & 0.89 \\
\hline ICRT2 & $<-$ & ICRT & 0.81 & 0.05 & 17.24 & $* * *$ & 0.78 \\
\hline ICRT3 & $<-$ & ICRT & 1.07 & 0.05 & 22.88 & $* * *$ & 0.91 \\
\hline ICRT4 & $<-$ & ICRT & 1.01 & 0.05 & 22.25 & $* * *$ & 0.89 \\
\hline ICPR1 & $<-$ & ISPR & 1 & & & & 0.7 \\
\hline ICPR2 & $<-$ & ISPR & 0.99 & 0.08 & 12.9 & $* * *$ & 0.84 \\
\hline ICPR3 & $<-$ & ISPR & 0.86 & 0.07 & 12.35 & $* * *$ & 0.8 \\
\hline ICPR4 & $<-$ & ISPR & 1.22 & 0.09 & 12.96 & $* * *$ & 0.85 \\
\hline ICIN1 & $<-$ & ICIN & 1 & & & & 0.6 \\
\hline ICIN2 & $<-$ & ICIN & 1.45 & 0.18 & 8.05 & $* * *$ & 0.53 \\
\hline ICIN3 & $<-$ & ICIN & 1.38 & 0.2 & 6.99 & $* * *$ & 0.97 \\
\hline
\end{tabular}

Source: Authors' Calculation

To sum up, the 6 key dimensions of Intrapreneurship that are confirmed and validated are "Self Renewal, New Business Venturing, Competitive Aggressiveness, Risk-taking, Proactiveness, and Innovativeness". One item ICIN4 was dropped due to low loading. 


\section{Conclusion}

The implications drawn in context of auto clusters in Delhi NCR is that they should consolidate the Intrapreneurship dimensions of Self renewal, New business venturing and Competitive aggressiveness. Self renewal can be realized through collateral structures that would enhance exchange of knowledge and partnering with the OEM in case of auto clusters.

More importantly, the main benefit of any clusters due to concentration is networking and sharing a common resource base. So, these attributes favour prospects of Self Renewal and New business venturing through increased innovation. This calls for establishing procedures for idea generation, ensuring autonomy in the work departments. New venturing relates to venturing out into new markets (sourcing) and in the related industries. The Intrapreneurship dimensions of Self renewal is in conformity with study of (Guth and Ginsberg 1990; Zahra 1991) who opined that Self renewal implies strategic and organizational change connotations through reorienting businesses, reorganizing and the introducing system-wide changes for innovation. At the same time Competitive aggressiveness can be fostered by winning over competitors or nurturing alliances with them.

It can also be implied in this study that the auto cluster firms need to work upon the Intrapreneurship dimensions of Risk-taking, Innovativeness and Proactiveness. The Risk taking capabilities and risk endurance to achieve objectives with high returns/ profit margins is important in case of auto clusters. This is consistent with Fellnhofer, et al. (2017) view point of aligning risk-taking with top management orientation in pursuit of competitiveness and also as individual's propensity to take risk (Kelley et al., 2011; Kollmann et al., 2017).

It can also be concluded that in case of auto clusters, Innovativeness should be considered as the thrust area which needs to be developed to a large extent in product line diversification and investing in R\&D, technological and leadership innovation. Proactiveness is also affirmed as an important dimension of Intrapreneurship in conformance with the study of (Chen et al., 2015; Hornsby et al., 2009; Parker and Collins, 2010) who asserted that proactive employees tend to challenge contemporary job roles in light of competition and assume entrepreneurial leadership roles. So, management in auto clusters need to identify proactive employees and assign them roles to implement change and assume leadership roles for enhanced performance.

Despite the important findings, the few limitations of the study which were encountered in this study were first, on account of small sample size which is confined to Delhi/NCR only. So, future studies may regard large samples in different geographical locations. Second, it has not included control variables (firm size, operations, etc.).Third, the dimensions of Intrapreneurship weren't linked with outcomes, as performance or productivity so further refinements to overcome these limitations suggests scope for similar studies in this domain. Besides, the scope extends to other longitudinal research that can also be done in other clusters in various locations. Moreover, each dimension of intrapreneurship can be examined in detail with related constructs, like organizational culture satisfaction, etc.in the context of clusters. Further, scope of this study extends to similar studies in different industries, to examine each of the key Intrapreneurship dimensions that have not been covered so far, to examine the antecedents of Intrapreneurship and impact of these dimensions on outcomes, as firm performance, growth and profitability. 


\section{References}

Alam, M., Nasir, N. \& Rehman, C. (2020). Intrapreneurship concepts for engineers: a systematic review of the literature on its theoretical foundations and agenda for future research.J Innov Entrep 9, 8 https:// doi.org/ 10.1186/s13731-020-00119-3.

Antoncic, B., \& Hisrich, R. D. (2001). Intrapreneurship: Construct refinement and cross-cultural validation. Journal of Business Venturing, 16(5), 495-527.

Antoncic, B., \& Hisrich, R. D. (2003). Clarifying the intrapreneurship concept. Journal of Small Business and Enterprise Development, 10(1), 7-24.

Antoncic, B., \& Hisrich, R. D. (2004). Corporate entrepreneurship contingencies and organizational wealth creation. Journal of Management Development, 23(6), 518-550.

Augusto Felício, J., Rodrigues, R., \& Caldeirinha, V. R. (2012). The effect of intrapreneurship on corporate performance. Management Decision, 50(10), 1717-1738.

Bagheri, A., Pihie, Z., and Krauss, S. (2013). Entrepreneurial leadership competencies among Malaysian university student entrepreneurial leaders. Asia Pacific Journal of Education 33(4), 493-508.

Baylor, A., \& Ritchie, D. (2002). What factors facilitate teacher skill, teacher morale, and perceived student learning in technology-using classrooms? Computers and Education 39(4), 395-414.

Blanka, C. (2019). An individual-level perspective on intrapreneurship: a review and ways forward. Rev Manag Sci 13, 919-961 https://doi.org/10.1007/s11846-018-0277-0

Carree, M.A., \& Thurik, R. (2003). “The impact of entrepreneurship on economic growth", in Audretsch, D.B. and Acs, Z.J. (Eds), Handbook of Entrepreneurship Research, Kluwer, Boston, MA, pp. 437-71.

Champathes Rodsutti, M., \& Swierczek, F. W. (2002). Leadership and organizational effectiveness in multinational enterprises in Southeast Asia. Leadership and Organization Development Journal, 23(5), 250-259.

Chawla, S., \& Lenka, U. (2015). A study on learning organizations in Indian higher educational institutes. Journal of Workplace Learning, 27(2), 142-161.

Chen, M. H., Chang, Y. Y., \& Chang, Y. C. (2015). Entrepreneurial orientation, social networks, and creative performance: Middle managers as corporate entrepreneurs. Creativity and Innovation Management, 24(3), 493507.

Covin, J.G., \& Slevin, D.P. (1989). Strategic management of small firms in hostile and benign environments, Strategic Management Journal, 10, 75-87.

Covin, J.G., \& Slevin, D.P. (1991). A conceptual model of entrepreneurship as firm behavior, Entrepreneurship Theory \& Practice, 16 (1), 7-25.

Damanpour, F. (1996). Organizational complexity and innovation: developing and testing multiple contingency models, Management Science, 42 (5), 693-716.

Fellnhofer, K. (2017). Drivers of innovation success in sustainable businesses. Journal of Cleaner Production, 167, 1534-1545.

Fernald, L., Solomon, G., \& Tarabishy, A. (2005). A new paradigm: Entrepreneurial leadership. Southern Business Review 30(2), 1-10.

Floyd, S. W., \& Wooldridge, B. (1999). Knowledge creation and social networks in corporate entrepreneurship: The renewal of organizational capability. Entrepreneurship Theory and Practice, 23(3), 123-144.

Fornell, C., \& Larcker, D. F. (1981). Evaluating structural equation models with unobservable variables and measurement error. Journal of Marketing Research, 18(1), 39-50. 
Gefen, D., Straub, D., \& Boudreau, M. C. (2000). Structural equation modeling and regression: Guidelines for research practice. Communications of the Association for Information Systems, 4(1), 7.

Guth, W.D., \& Ginsberg, A. (1990). Guest editors' introduction: corporate entrepreneurship, Strategic Management Journal, 11 (1), 5-15.

Guttman, L. (1954). "Some necessary conditions for common-factor analysis," Psychometrika, 19, 149-161.

Hair, J. F., Black, W. C., Babin, B. J., Anderson, R. E., \& Tatham, R. L. (2009). Multivariate Data Analysis (7th ed.). Upper Saddle River, New Jersey: Pearson Education Limited.

Hooper, D., Coughlan, J., \& Mullen, M. (2008). Evaluating model fit: a synthesis of the structural equation modelling literature. In the 7th European Conference on research methodology for business and management studies (195-200).

Hornsby, J. S., Kuratko, D. F., \& Zahra, S. A. (2002). Middle managers' perception of the internal environment for corporate entrepreneurship: Assessing a measurement scale. Journal of Business Venturing, 17(3), 253-273.

Hornsby, J. S., Kuratko, D. F., Shepherd, D. A., \& Bott, J. P. (2009). Managers' corporate entrepreneurial actions: Examining perception and position. Journal of. Business Venturing, 24(3), 236-247. doi: 10.1016/ j.jbusvent.2008.03.002.

Hu, L. T., \& Bentler, P. M. (1999). Cutoff criteria for fit indexes in covariance structure analysis: Conventional criteria versus new alternatives. Structural Equation Modeling: A Multidisciplinary Journal, 6(1), 1-55.

Jiang, X. (2009). Strategic management for main functional areas in an organization. International Journal of Business and Management, 4(2), 153-157.

Kakati, M. (2003). Success criteria in high-tech new ventures. Technovation, 23(5), 447-457.

Kassa, A. \& Raju, R. (2015). Investigating the relationship between corporate entrepreneurship and employee engagement. Journal of Entrepreneurship in Emerging Economies, 7(2), 148-167.

Kelley, D. J., O’Connor, G. C., Neck, H., \& Peters, L. (2011). Building an organizational capability for radical innovation: the direct managerial role. Journal of Engineering and Technology Management, 28(4), 249-267.

Knight, G.A. (1997). Cross-cultural reliability and validity of a scale to measure firm entrepreneurial orientation, Journal of Business Venturing, 12 (3), 213-25.

Kollmann, T., Stockmann, C., Meves, Y., \& Kensbock, J. M. (2017). When members of entrepreneurial teams differ: Linking diversity in individual-level entrepreneurial orientation to team performance. Small Business Economics, 48(4), 843-859.

Kuratko, D. (2007). Entrepreneurial leadership in the 21st century: Guest editor's perspective. Journal of Leadership \& Organizational Studies 13(4), 1-11.

Lukes, M., \& Stephan, U. (2017). Measuring employee innovation: a review of existing scales and the development of the innovative behavior and innovation support inventories across cultures. International Journal of Entrepreneurial Behavior \& Research, 23(1), 136-158.

Miles, M. P., \& Covin, J. G. (2002). Exploring the practice of corporate venturing: Some common forms and their organizational implications. Entrepreneurship Theory and Practice, 26(3), 21-40.

Mundfrom, D. J., Shaw, D. G., \& Ke, T. L. (2005). Minimum sample size recommendations for conducting factor analyses. International Journal of Testing, 5(2), 159-168.

Neessen, P. C. M., Caniëls, M. C. J., Vos, B., \& de Jong, J. P. (2019). The intrapreneurial employees: Towards an integrated model of intrapreneurship and research agenda. International Entrepreneurship and Management Journal, 15(2), 545-571. doi:10.1007/s11365-018-0552-1. 
Parker, S. K., \& Collins, C. G. (2010). Taking stock: Integrating and differentiating multiple proactive behaviors. Journal of Management, 36(3), 633-662.

Parker S.C. (2011). Intrapreneurship or entrepreneurship?, Journal of Business Venturing, 26 (1), 19-34.

Pinchot, G., \& Pellmann, R. (1999). 'Intrapreneuring in action: A handbook of business innovation. San Francisco: Barrett-Koehler Publication.

Pinchot, G. (1985). Intrapreneuring: Why you don't have to leave the corporation to become an entrepreneur, NY: Harper and Row.

Rule, E. G., \& Irwin, D. W. (1988). Fostering intrapreneurship: The new competitive edge. Journal of Business Strategy, 9(3), 44-47.

Stevenson, H.H., \& Jarillo, J.C. (1990). A paradigm of entrepreneurship: entrepreneurial management, Strategic Management Journal, 11, Summer, 17-27.

Stopford, J. M., \& Baden-Fuller, C. (1990). Corporate rejuvenation. Journal of Management Studies, 27(4), 399-415.

Stopford, J. M., \& Baden-Fuller, C. W. (1994). Creating corporate entrepreneurship. Strategic Management Journal, 15(7), 521-536.

Tabachnick, B.G., \& Fidell, L.S., Using multivariate statistics (6th ed.), Pearson, 2013.

Tushman, M.L., \& Anderson, P. (Eds) (1997). Managing Strategic Innovation and Change: A Collection of Readings, Oxford University Press, New York, NY.

Vargas-Halabí, T., Mora-Esquivel, R., \& Siles, B. (2017). Intrapreneurial competencies: Development and validation of a measurement scale. European Journal of Management and Business Economics, 26(1), 86-111.

Vesper, K.H. (1984). “Three faces of corporate entrepreneurship”, in Hornaday, J.A., Timmons, J.A. and Vesper, K.H. (Eds), Frontiers of Entrepreneurship Research, Babson College, Wellesley, MA, 294-320.

Wennekers, S., \& Thurik, R. (1999). Linking entrepreneurship and economic growth, Small Business Economics, 13 (1), 27-55.

Wiklund, J., \& Shepherd, D. (2003). Knowledge-based resources, entrepreneurial orientation, and the performance of small and medium-sized businesses. Strategic Management Journal, 24(13), 1307-1314.

Zaech, S., \& Baldegger, U. (2017). Leadership in start-ups. International Small Business Journal: Researching Entrepreneurship 35(2), 157-177.

Zahra, S.A. (1991). Predictors and financial outcomes of corporate entrepreneurship: an exploratory study, Journal of Business Venturing, 6 (4), 259-85. 